\title{
Evaluation of the SR Portland cement against sodium and magnesium sulfate attack: a physical and comparative analysis of mortars
}

\section{Avaliação do cimento Portland RS frente ao ataque por sulfato de sódio e magnésio: uma análise física e comparativa em argamassas}
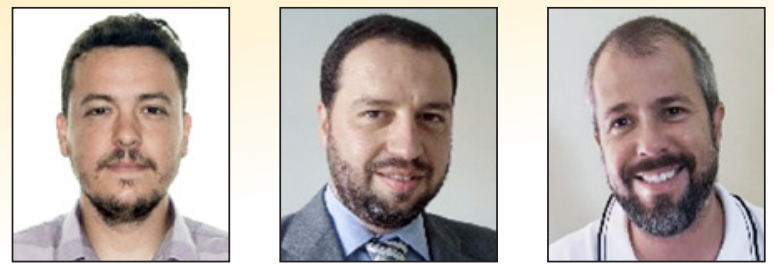

D. J. DE SOUZA diegojesusdesouza@hotmail.com

M. H. F. MEDEIROS medeiros.ufpr@gmail.com

J. HOPPE FILHO juarez.hoppe@gmail.com

\section{Abstract}

Sulfate attack is a term used to describe a series of chemical reactions between sulfate ions and hydrated compounds of the hardened cement paste. Thus, the chemical composition of the binders used is important for the durability of the structure against this aggressive agent. The objective of the present research is to evaluate the influence of sodium and magnesium sulfates on physical properties (linear expansion, flexure tensile strength, and compressive strength) of mortars composed by SR cement (CP V - ARI RS), as commercially sold in Brazil. The results indicate that SR cement complies the requirements established by Brazilian standards, as to chemical composition and resistance to sodium sulfate. However, for magnesium sulfate, SR cement was harmful to mortars mainly in mechanical.

Keywords: durability, sulfate attack, sodium sulfate, magnesium sulfate.

\section{Resumo}

O ataque por sulfatos é um termo usado para descrever uma série de reações químicas entre íons sulfato e compostos hidratados da pasta de cimento endurecida. Deste modo, a composição química dos aglomerantes utilizados é de suma importância para a durabilidade da estrutura frente a este agente agressivo. O presente trabalho objetiva a avaliação das propriedades físicas (expansão linear, resistência à tração na flexão e de resistência à compressão) de argamassas compostas por cimento do tipo RS (CP V - ARI RS), conforme comercialmente vendido no Brasil, frente ao ataque por sulfatos de sódio e de magnésio. Os resultados indicam que o cimento RS cumpre as exigências estabelecidas por norma, quanto à composição química e quanto à resistência ao sulfato de sódio. Porém, para o sulfato de magnésio, o cimento RS foi prejudicial às argamassas, pincipalmente nas avaliações de resistências mecânicas. Indicando que este cimento RS não é uma boa opção para exposição ao MgSO ${ }_{4}$.

Palavras-chave: durabilidade, ataque por sulfatos, sulfato de sódio, sulfato de magnésio. 


\section{Introduction}

Concrete deterioration can be caused by physical, chemical, or a combination of both. Sulfate attack is a term used to describe a series of chemical reactions between sulfate ions and hydrated compounds of the hardened cement paste. In comparison to other aggressive chemical reactions, sulfates are most damaging to concrete when present in the form of gases or liquids [1][2][3][4].

The classical form of sulfate attack, associated with the formation of gypsum and the secondary ettringite, is the most common form of sulfate attack, resulting from the diffusion of sulfate ions from an external source [5]. The interaction between sulfate ions and hydrated Portland cement products, such as calcium hydroxide, to form gypsum; and, with aluminates, to form ettringite, can increase the volume, about 1.2 to 2.2 times, then the initial products and, as consequence, there is formation of internal stresses in the cement paste, which can cause expansion, cracking and resulting in damage [3][6]. Several studies indicate that $\mathrm{MgSO}_{4}$ solutions are more aggressive to concrete than $\mathrm{Na}_{2} \mathrm{SO}_{4}$ solutions at the same exposure conditions [2][7][8][9][10][11]. In the sodium sulfate solution, the reaction with the hydrated products of the cement occurs, in the main part, with the ions $\mathrm{SO}_{4}{ }^{2-}$, and its main reaction is with the calcium hydroxide $\mathrm{Ca}(\mathrm{OH})_{2}$, forming gypsum, and, when there is also interaction between gypsum and aluminates phases (AFm), there is the formation of ettringite [8], while $\mathrm{Na}^{+}$ions interact with the $\mathrm{OH}^{-}$released in the formation of the gypsum, causing a small increase in $\mathrm{pH}$, which can work as a catalyst for the deleterious reaction and also for stabilization of the ettringite [9]. Whereas for the magnesium sulfate solution, in addition to the common reaction with the $\mathrm{SO}_{4}^{2-}$ ions, there is also deleterious reaction with $\mathrm{Mg}^{2+}$ ions. Thus, $\mathrm{MgSO}_{4}$ has its reaction with $\mathrm{Ca}(\mathrm{OH})_{2}$ forming brucite $\left[\mathrm{Mg}(\mathrm{OH})_{2}\right]$ and gypsum, ettringite (in interaction with aluminate phases) and also can react with the $\mathrm{C}$ -
$\mathrm{S}-\mathrm{H}$, where there is the decalcification of calcium silicate hydrated and formation of magnesium silicate hydrated $(\mathrm{MSH})$, which has no cementitious properties [12][13].

According to ABNT NBR 5.737 [14], to be considered as resistant to sulfates, Portland cement must meet the following specifications:

- The $\mathrm{C}_{3} \mathrm{~A}$ content in the clinker must be equal to or less than $8 \%$ and with a carbonaceous content equal to or less than $5 \%$ of the total mass of the binder;

Blast furnace slag content between $60 \%$ and $70 \%$ (for blast furnace Portland cement);

- The content of pozzolanic materials between $25 \%$ and $40 \%$ (for pozzolanic Portland cement).

This standard establishes the Bogue equation (Eq.1) as a method of obtaining the amount of $\mathrm{C}_{3} \mathrm{~A}$ in the clinker.

$\left(C_{3} A\right)=2,650 \cdot\left(\mathrm{Al}_{2} \mathrm{O}_{3}\right)-1,692 \cdot\left(\mathrm{Fe}_{2} \mathrm{O}_{3}\right)$

Where:

$\left(\mathrm{Al}_{2} \mathrm{O}_{3}\right)$ and $\left(\mathrm{Fe}_{2} \mathrm{O}_{3}\right)$ are contents that are just present in clinker chemical composition.

Since $\mathrm{SO}_{4}^{2-}$ concentration is high, regarding sulfate attack conditions, $\mathrm{C}_{3} \mathrm{~A}$ contents below $9 \%$ usually show acceptable performance to sulfates, differently from amounts higher than $12 \%$. While in the range of both shows variable behavior [15].

Tosun-Felekoglu [16] shows results from samples with different amounts of $\mathrm{C}_{3} \mathrm{~A}(4.6 \%$ and $11.2 \%)$ and also using limestone filler $(0 \%, 5 \%, 10 \%, 20 \%$ and $40 \%$ in partial replacement of the cement, by mass) exposed to both magnesium and sodium sulfate solutions at two different temperatures ( 5 and $20^{\circ} \mathrm{C}$ ). According to the author, the deterioration of the samples was much more significant in concretes containing $11.2 \%$ of $\mathrm{C}_{3} \mathrm{~A}$, for both solutions. Likewise, this has become even more critical in conditions where there are higher cement replacement levels, due to the increase in

Evaluation of the sulfate attack on Portland cement mortar properties

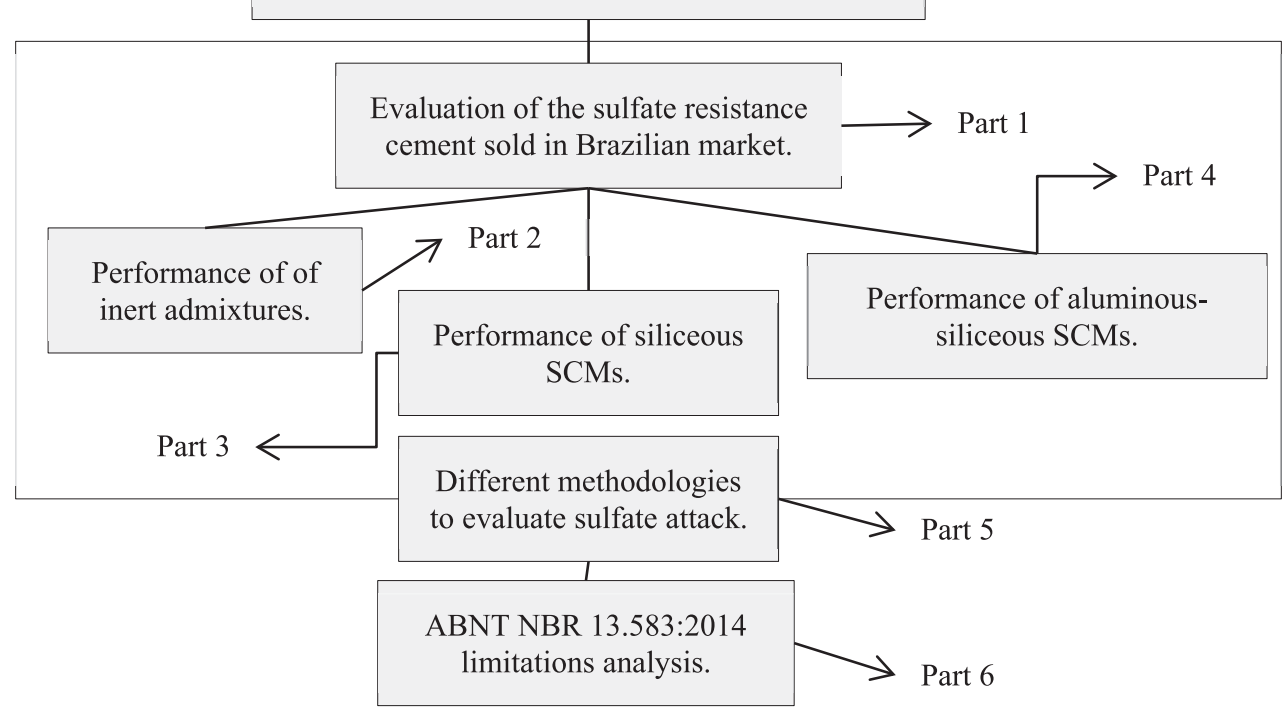

\section{Figure 1}

Division of the research project to evaluate sulfate attack on the properties of Portland cement mortars 
Table 1

Chemical composition of the cements CPV - ARI and CPV - ARI RS

\begin{tabular}{|c|c|c|c|c|c|c|c|c|c|c|}
\hline \multirow[b]{2}{*}{ Binder } & \multicolumn{10}{|c|}{ Chemical analysis (\%) } \\
\hline & $\mathrm{CaO}$ & $\mathrm{SiO}_{2}$ & $\mathrm{Al}_{2} \mathrm{O}_{3}$ & $\mathrm{Fe}_{2} \mathrm{O}_{3}$ & $\mathrm{MgO}$ & $\mathrm{SO}_{3}$ & $\mathrm{~K}_{2} \mathrm{O}$ & $\mathrm{CaO}$ free & $\begin{array}{c}\text { Res. } \\
\text { insoluble }\end{array}$ & $\begin{array}{l}\text { Loss } \\
\text { of fire }\end{array}$ \\
\hline CP V-ARI & 59.36 & 16.27 & 5.06 & 2.77 & 4.63 & 5.30 & 1.06 & 1.46 & 0.67 & 3.43 \\
\hline CP V-ARI RS & 55.40 & 20.10 & 4.80 & 3.50 & 5.60 & 2.80 & 1.00 & - & 0.90 & 5.97 \\
\hline
\end{tabular}

permeability, especially at lower ages, and, there was an increase in the formation of thaumasite that had been aggravated at lower temperatures. A similar result was obtained by Hossack and Thomas [17] using cement with moderate levels of $\mathrm{C}_{3} \mathrm{~A}(8-9 \%)$ and high (11-12\%) and also adding limestone filler.

According to Skalny et al. [2], $\mathrm{C}_{4} \mathrm{AF}$ can produce ettringite as well, however, at a considerably lower rate than $\mathrm{C}_{3} \mathrm{~A}$, as so cements with lower $\mathrm{C}_{3} \mathrm{~A} / \mathrm{C}_{4} \mathrm{AF}$ ratio can are, in general, causes less expansion. Regarding silicates phases of the clinker, as the ratio $C_{3} S / C_{2} S$ of the clinker increases, greater is be the formation of portlandite after hydration, which results in a concrete more susceptible to sulfate attack [15]. Different author [18][19] also indicated that there is greater resistance to sulfate attack in cement with low $\mathrm{Ca} / \mathrm{Si}$ ratio, which also leads to a lower portlandite formation after hydration. However, Taylor [20] argue that cement containing supplementary cementitious materials (SCMs), which generally reduce the free amount of calcium hydroxide, may turn the concrete more susceptible to magnesium sulfates attack. Since this type of sulfate can react with the $\mathrm{CSH}$, which presents lower degradation when $\mathrm{Ca}(\mathrm{OH})_{2}$ is present due to $\mathrm{pH}$ control.

The present paper is the first part of a research project to evaluate the sulfate attack on the physical-chemical properties of Portland cement composites, developed at the Federal University of Paraná (Figure 1).

The objective of this paper is to evaluate the performance of physical properties (linear dimensional expansion, tensile strength in flexion and compressive strength) of cement mortars of the type resistant to sulfates (CP V - ARI RS) as commercially sold in Brazil, against the attack by sodium and magnesium sulfates. The approach of the problem will involve the manipulation of two independent variables, the type Portland cement studied (CP V - ARI and CP V - ARI RS) and the aggressive solution of exposure of the mortars, in models of experimental technical procedures, that seek the quantitative detection and qualitative results.

\section{Materials and methods}

In order to detect the influence of the cement type on sulfate attack damage degree, the present research has as a main concern, the evaluation of the interference of the sulfate ions in the physical properties intrinsic to the proposed objective.

\subsection{Materials}

a) Binder materials (CPV - ARI and CPV - ARI RS)

The choice of these binders was due to their composition, which is basically clinker and gypsum, and both are the commercial cement with the largest quantity of clinker in the Brazilian market. Thus, there is no influence of any mineral addition on the reference system to be evaluated, other than the permitted carbonaceous material content per standard. It is also mentioned that this cement type V (CP V-ARI and CP V-ARI RS) is very used in precast concrete industry in Brazil due, in particular, to its capacity of high initial strength development. The use of CP V-ARI RS Portland cement was also commercially sold as sulfate resistant (RS).

For characterization of the cement, the loss on ignition tests was according to ABNT NBR NM 18 criteria [21] were used; for specific gravity was used Le Chatelier flask, with a volumetric capacity of $250 \mathrm{~cm}^{3}$ [22]. Since this standard specifies that the liquid to be used should not chemically react with the materials tested and it must have a density of $0,731 \mathrm{~g} / \mathrm{cm}^{3}$ or more, it was decided to use kerosene for the tests; Blaine specific area was also determined [23]. Chemical analyzes were also performed, by the use of X-ray Fluorescence; and, particle size distribution was measured using laser diffraction in a measurement range of 0.04-500 $\mu \mathrm{m}$.

Table 1 shows the chemical compositions of the CP V - ARI (ARI) and CP V - ARI RS (RS) cements according to the results obtained from the X-ray fluorescence. Table 2 presents the physical characteristics of the cement.

When is compared the chemical analyses of both cements, it is seen that the RS has an amount of calcium oxide 3.96\% lower than $\mathrm{ARI}$, and the content of $\mathrm{SiO}_{2}$ is $3.83 \%$ higher, the content of aluminate is $0.26 \%$ lower, and, last but not least, the content of $\mathrm{Fe}_{2} \mathrm{O}_{3}$ is $0.73 \%$ higher. These results have a direct impact on the capacity of the cement to form after hydration products that can react with sulfate ions. The decrease in the $\mathrm{Ca} / \mathrm{Si}$ ratio from 3.65 (ARI) to 2.76 (RS) results in a consequent lower $\mathrm{C}_{3} \mathrm{~S}$ content, as well as lower $\mathrm{Ca}(\mathrm{OH})_{2}$ formation after hydration [18][19].

Likewise, the decrease on the aluminate amount and an increase in $\mathrm{Fe}_{2} \mathrm{O}_{3}$ also have a positive influence on final products susceptible to sulfate attack after hydration [2][15], since a smaller formation of calcium monosulfoaluminate hydrated, which is directly related to the formation secondary ettringite.

However, cement with a lower amount of calcium hydroxide can turn

Table 2

Physical analysis of the cement

\begin{tabular}{|c|c|c|}
\hline \multirow{2}{*}{ Binder } & \multicolumn{2}{|c|}{ Physical analysis } \\
\cline { 2 - 3 } & $\begin{array}{c}\text { Blaine } \\
\left(\mathbf{c m}^{2} / \mathbf{g}\right)\end{array}$ & $\begin{array}{c}\text { Specific gravity } \\
\left(\mathbf{g} / \mathbf{c m}^{3}\right)\end{array}$ \\
\hline CPV-ARI & 4.510 & 3.13 \\
\hline CPV-ARI RS & 5.030 & 3.11 \\
\hline
\end{tabular}


the concrete more susceptible to magnesium sulfates attack, due to the possibility of the instability of C-S-H due to o lower $\mathrm{pH}$ [20].

With the results of the physical-chemical characterization of the cement, it was observed that the ARI used was in disagreement with the standard for the high initial strength cement. The total amount of sulfur trioxide is limited to a $\mathrm{C}_{3} \mathrm{~A}$ content greater than $8 \%$ should be up to $4.5 \%$. However, with the chemical analysis, it was obtained that the amount of $\mathrm{SO}_{3}$ was $5.3 \%$. In parallel, the RS cement presented as $\mathrm{C}_{3} \mathrm{~A}$ content values according to the ABNT NBR 5.737 [14] recommendations, so it can be considered as resistant to sulfates, indeed. Finally, by graphical analysis from the granulometric distribution shown in Figure 2, it can be observed that the CP V-ARI has a mean distribution of the particles about $1 \mu \mathrm{m}$ higher than the RS cement ( $6 \mu \mathrm{m}$ for the ARI and $5 \mu \mathrm{m}$ for the RS).

\section{b) Fine aggregate}

The fine aggregate used for the mortars composition was the Brazilian standard sand [24]. The use of this aggregate is due to the requirements of NBR 13.583 [25] since it has little influence on the results and also it is free of contaminants. Considering that the objective of the study is to analyze just the influence of the binder material under sulfate attack, the choice of this material became necessary.

\subsection{Methods to evaluate sulfate attack}

In this section will present the procedures used to evaluate the sulfate attack in different prismatic mortars bars, such as preparing procedure of the samples; solutions; conditions of exposure; length variation test and compressive strength test.

\section{a) Preparing of the sample for mortar bar tests}

The damage degree of sulfate attack on mortars was analyzed, in general, by the using of two main groups:

- Group 1: composed by 24 specimens with dimensions of 25 $\mathrm{mm} \times 25 \mathrm{~mm} \times 285 \mathrm{~mm}$ (intended for the measurements of length variation), divided into 2 different binders' composition and 3 different final exposure solutions;

- Group 2: composed of 72 specimens with dimensions of 40 $\mathrm{mm} \times 40 \mathrm{~mm} \times 160 \mathrm{~mm}$ to evaluate variations in compressive strength, also into 2 different binders' composition and 3 different final exposure solutions.

Both groups of specimens were exposed to three different solutions, as mentioned above, $\left(\mathrm{xH}_{2} \mathrm{O}+\mathrm{Na}_{2} \mathrm{SO}_{4}, \mathrm{xH}_{2} \mathrm{O}+\mathrm{MgSO}_{4}\right.$ and $\left.\mathrm{xH}_{2} \mathrm{O}+\mathrm{Ca}(\mathrm{OH})_{2}\right)$, in this way the evaluation of th,e sulfate attack could be distributed according to the size of the CPs.

The mix-design of the mortars followed NBR 13.583 [25] recommendation. Then, considering that the fine aggregates and batch water were the same used for both compositions, the only thing that differs between both series was just binder composition, CP V - ARI (ARI) and CP V - ARI RS (RS).

The batching process was performed according to ABNT NBR 7.215 [26] and the specimens were molded and taken to the curing procedures as ABNT NBR 13.583 [25]; however, the exposure time was extended from 42 to 140 days.

\section{b) Exposure solutions}

After $48 \mathrm{~h}$ of curing at $23^{\circ} \mathrm{C}$ and $100 \%$ of R.H. and 12 days of curing at $23^{\circ} \mathrm{C}$ and immersed in solution of water saturated with lime [25], the specimens were then immersed in the final solution, sulfates or reference solutions (water with lime), where they were kept for 140 days as described above. The concentration of anhydrous sodium sulfate used was $100 \mathrm{~g}$ of $\mathrm{Na}_{2} \mathrm{SO}_{4} / \mathrm{L}$ of the solution [25]. Therefore, due to the molar mass of sulfur and oxygen the $\mathrm{SO}_{4}{ }_{4}^{2-}$ concentration were defined as $67,630 \mathrm{ppm}(67.63 \mathrm{~g} / \mathrm{L})$. Fixing this result, by stoichiometry, the magnesium sulfate solution was prepared, in other

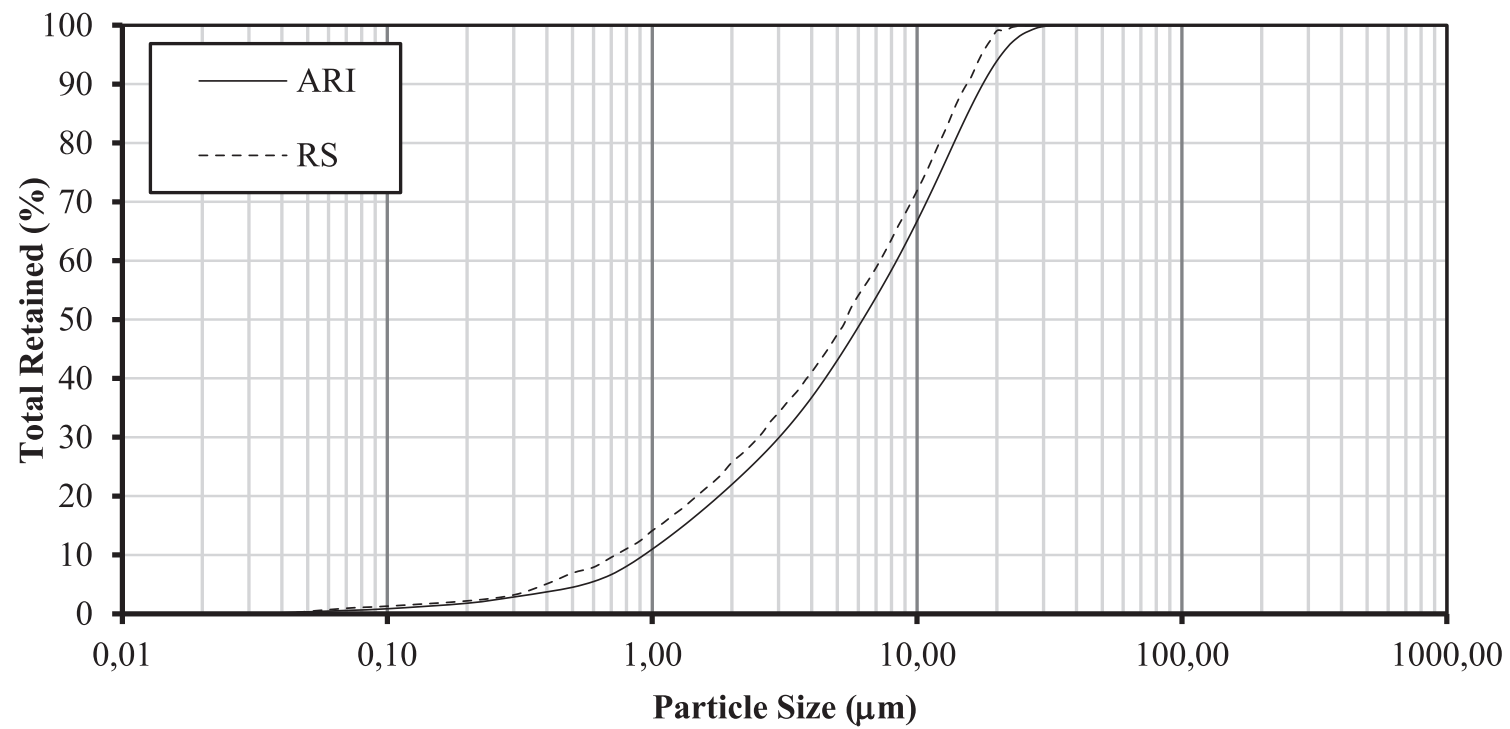

Figure 2

Particle size distribution of the binder materials 


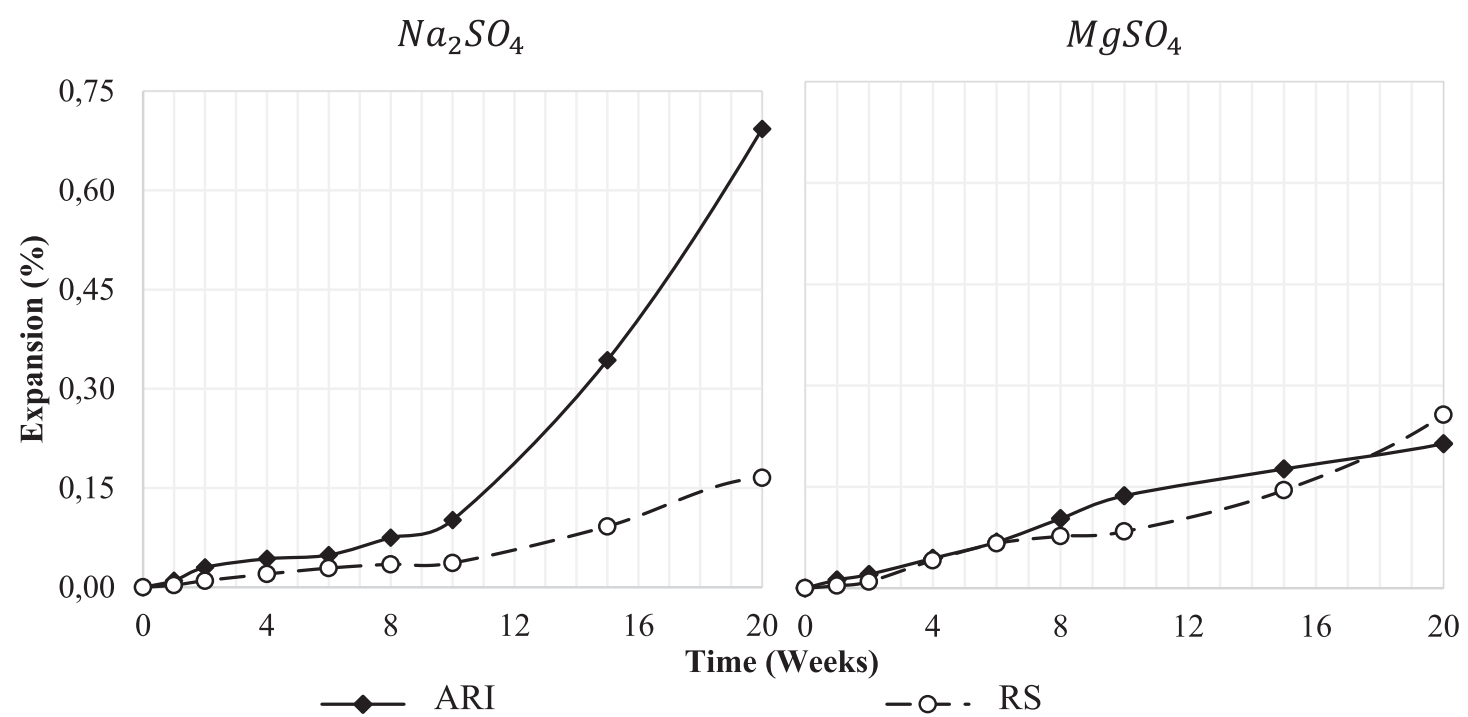

Figure 3

Expansion of the samples up to 20 weeks of exposure to sodium and magnesium sulfate solutions

words, the sulfate content in solution was fixed at $6.76 \%$ per liter. Finally, the ration between volumes solution/samples were kept as 4.0/1.0 [25]

\section{c) Length variation}

The evaluation of length variation followed NBR 13.583 [25] recommendation as well, however, with extended exposure time. Thus, after the first curing (48h) and second curing (12 days) procedures, the samples had their initial lengths measured, so that they were exposed to the final solutions.

The measurements were performed after 2, 4, 6, 8, 10, 15 and 20 weeks of exposure. For this purpose, the samples were placed at the micrometer apparatus, always with the same face upwards, and the measurements were taken always referring to the smaller length indication identified by the apparatus after $360^{\circ}$ rotation of the bar.

The individual expansion, or retraction, of the samples, is given by the difference between the value measured at the corresponding exposure time and the initial reading, divided by its initial length and multiplied by 100 .

\section{d) Compressive and flexural tensile strength}

The tests of flexural tensile and compression strength were made at times of exposure of $0 ; 2 ; 6 ; 10 ;$ and, 20 weeks. ABNT NBR 13.279 [27] recommendations were followed and the tests were carried out in an equipment with a load capacity of $100 \mathrm{kN}$, and the tensile strength tests were performed in the bars before the compression.

For the flexural tensile strength test the load application rate was $50 \pm 10 \mathrm{~N} / \mathrm{sec}$ until failure, thus, the strength was calculated according to ABNT NBR 13.279 [27].

In compressive strength test, 6 specimens were obtained after tensile tests of 3 samples and the load application rate was $505 \pm 5 \mathrm{~N} /$ sec until failure, thus, the strength was calculated.

\section{Results and discussions}

The results of the tests will be presented and discussed in this section, firstly length variation of and then the results related to mechanical properties.

\subsection{Length variation analysis}

The discussion methodology will follow initially the variations occurred for an exposure time of 42 days ( 6 weeks), focusing on the discussion of the exposure time of NBR 13.583, even though the standard does not address any commentaries related to immersion in magnesium sulfate solution. Consequently, the behaviors of the series will be discussed individually for the extended time of exposure. Thus, Figure 3 shows the development of the resulting expansion over the 140 days of exposure to both aggressive solutions, sodium sulfate and magnesium sulfate.

It should be noted that NBR 13.583 [25] does not specify a value to which a composition can be considered resistant or not to sulfate attack since it is only a comparative analysis. However, according to Marciano [28], compositions with expansion equal to or less than $0.030 \%$ at the 42 days of exposure (6 weeks) may be considered resistant to sodium sulfate. However, considering that the sulfate content in solution was kept constant at $6.76 \%$ per liter, it was observed that only RS exposed to sodium sulfate solution presented resistance (expansion equal to $0.029 \%$ ), considering the limit of $0.030 \%$.

On the other hand, still considering 42 days of exposure (6 weeks), RS did not achieve the same performance regarding exposure to magnesium sulfate, as well as ARI samples. In general, the series resulted in an expansion 1.8 times, on average, higher than those immersed in the $\mathrm{Na}_{2} \mathrm{SO}_{4}$ solution. This phenomenon can be explained by the fact that $\mathrm{MgSO}_{4}$ has solubility 5 times higher 


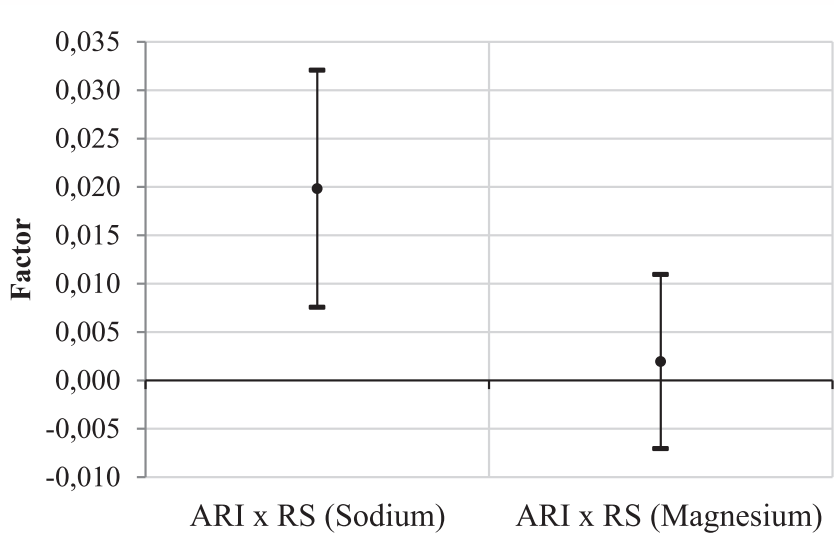

\section{Figure 4}

Comparative analysis of the averages, Tukey's test, for 6 weeks of exposure among the series studied, for a significance level of $5 \%$

than $\mathrm{Na}_{2} \mathrm{SO}_{4}$ and also, $\mathrm{SO}_{4}{ }^{2-}$ has a greater influence on the molar mass of magnesium sulfate. Therefore, providing a larger amount of sulfate ions, about 6.7 times (value can be obtained by simple stoichiometry), to reacts with the mortar bars.

The comparative analysis of the averages, Tukey's test, for 6 weeks of exposure, can be seen in Figure 4. Thus, it should be mentioned that with the analysis, the series can be considered statistically equivalent when exposed to magnesium sulfate, thus, the decision making for each binder should be used could be done based on economical and non-technical benefits for this case. However, a distinct behavior can be observed for sodium sulfate solution, it is seen that the use of CP V - ARI cement by the commercially sold as sulfate resistant (CP V - ARI RS) indeed provide technical advantages in terms of exposure to sodium sulfate, after all, the latter brought a resulting expansion $40.8 \%$ lower than the other cement. In the analysis for 140 days of exposure (20 weeks), in the comparison between both series, it was observed that CP V-ARI presented expansion 4.2 times higher than $\mathrm{RS}$ for exposure to $\mathrm{Na}_{2} \mathrm{SO}_{4}$ for 20 weeks. The explanation for this behavior can be based on Tikalsky et al. [15] publication, with a decrease in $C_{3} A / C_{4} A F$ ratio there is a delays on expansion process due to changes on the kinetics of the reaction. Since the production of ettringite from $\mathrm{C}_{4} \mathrm{AF}$ occurs in a slower rate than $\mathrm{C}_{3} \mathrm{~A}$, and, in fact, the expansion measured for RS was lower than ARI. However, changing sulfate solution, this statement does not have the same influence on results, since this behavior was not repeated for the case of exposure to magnesium sulfate.

\subsection{Flexural tensile strength analysis}

According to Marciano [28] publication, tensile strength is not a good parameter for monitoring the degradation due to sulfate attack, either flexural strength or splitting tensile strength (Brazilian test), especially for short exposure time.

However, Biczók [1] and Irassar [29] commented that the flexural strength test shows that the strength increases with exposure to sulfate attack up to a limit point, from which it starts to decrease. According to Irassar [29], it is possible to take from this parabolic behavior of the results the micro-cracking start time point of the samples. Which matches with the point at derivate is equal to zero. Thus, Figure 5 presents the flexural tensile strength results for

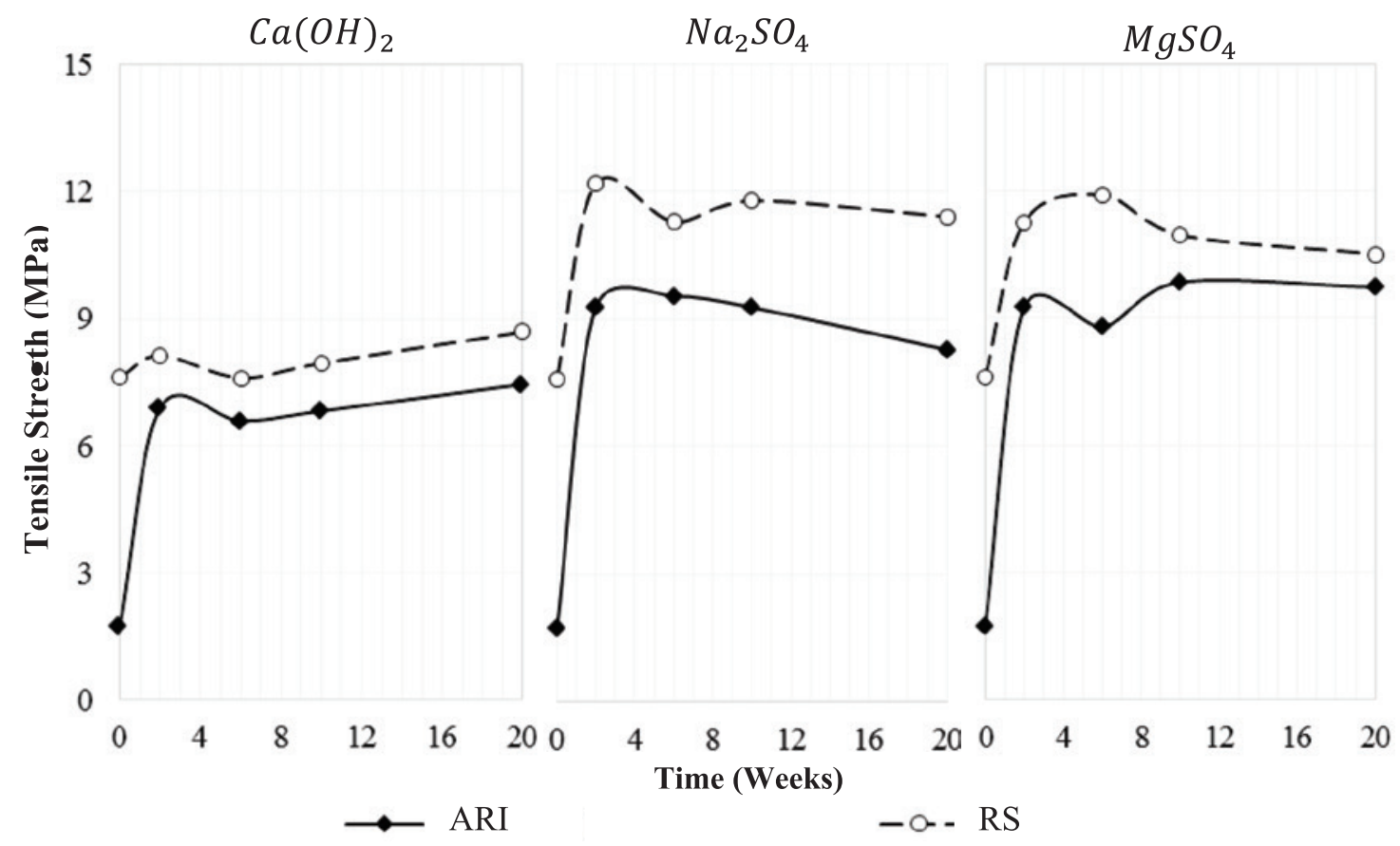

Figure 5

Tensile strength of the samples up to 20 weeks of exposure in the three different solutions $\left(\mathrm{Ca}[\mathrm{OH}]_{2}, \mathrm{Na}_{2} \mathrm{SO}_{4}\right.$ and $\left.\mathrm{MgSO}_{4}\right)$ 

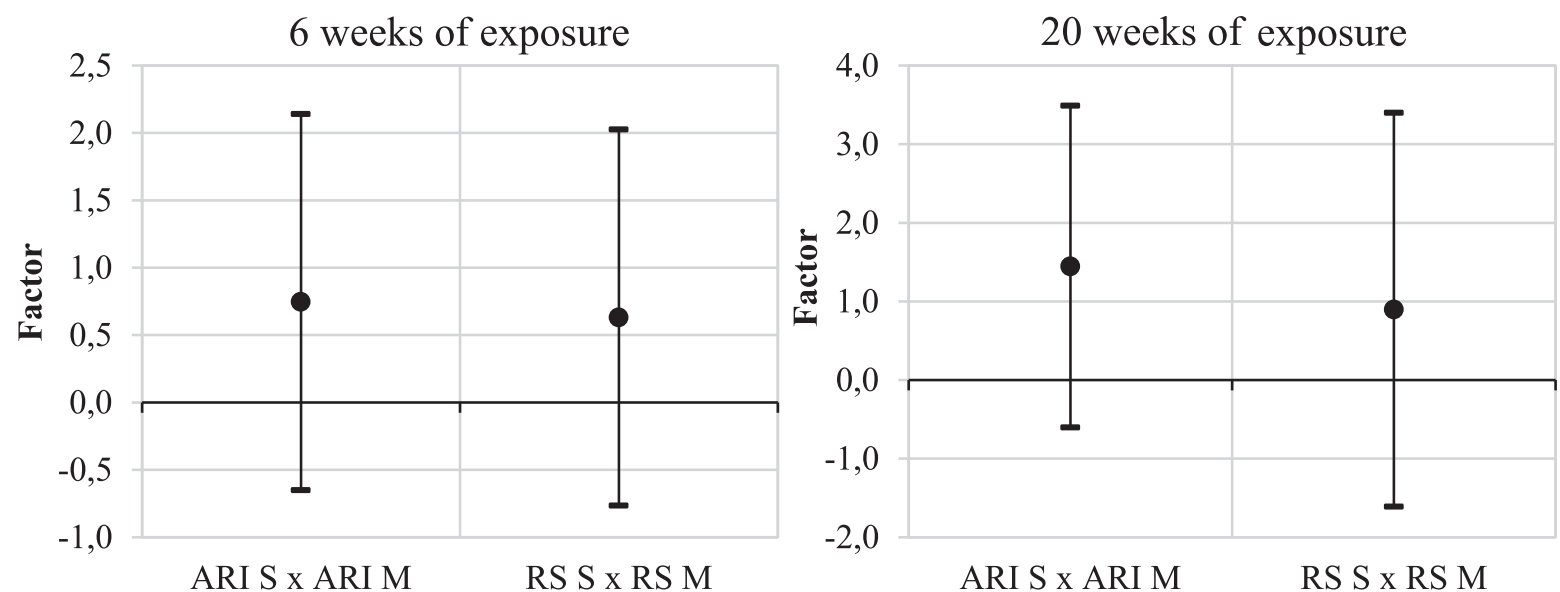

\section{Figure 6}

Comparative analysis between averages (Tukey's test for a significance level of $5 \%$ ) of the same series for different aggressive solutions ( $\mathrm{S}$ - sodium sulfate and $\mathrm{M}$ - magnesium sulfate) for 6 and 20 weeks of exposure

the series of samples up to 20 weeks of exposure to the three final solutions.

In general, the influence of the deleterious solutions increases tensile strength. It is also seen that both sulfate solutions showed similar behavior in the samples according, for example, to the results obtained by Huang et al. [30]. However, in the present work, such behaviors may even be considered statistically similar, as can be seen with Figure 6 which shows Tukey's test for comparative analysis between averages of the same series for different solutions.

It can be seen in Figure 5 that the samples exposed to the calcium hydroxide solution, in general, obtained a tendency to increase the resistance as a function of time, even though showing some variations in 6 and 10 weeks. In this way, it is assumed that the bars did not show cracks, as expected since the mortars remained in ideal conditions of curing. On the other hand, when subjected to sulfate solutions, in fact, based on Irassar [29] publication, show tendency of increasing strength over time to a certain point at which microcracking begins. Therefore, the polynomial equation for each of the series were obtained and then, the points to which its first derivate are equaled zero were also obtained, according to Table 3.

The reference series (ARI) showed an earlier degradation of exposure to sodium sulfate and lower than exposure to magnesium sulfate attack. Indicating, in this case, that $\mathrm{Na}_{2} \mathrm{SO}_{4}$ was more aggressive to this composition. However, RS samples presented opposite behavior when compared to the ARI samples. In other words, it presented delay micro-crack starting point for exposure to sodium sulfate but accelerated the degradation when exposed to magnesium sulfate.

Nevertheless, the values obtained do not directly correspond to the degree of sulfate attack for each of the samples, though, obtaining the cracking time proved to be the valuable result for determining the beginning of the degradation by the aggressive solutions.

\subsection{Compressive strength analysis}

Many of the literature and standards around the world, including ABNT NBR 13.583 [25] focus the evaluation of the sulfate attack just on length variation. Thus, in order to make the evaluation of the degree of attack more comprehensive and, at the same time, in an easier and cheap procedure, it was decided to analyze the variation of the compressive strength (as well tensile strength already mentioned) of specimens as a function of the sulfate attack development. Many authors [1][2][8][31][33][34] discuss and recommend the uses of compressive strength values as an essential parameter and with great importance to be considered, regarding the damage degree of sulfate attack, and the results obtained in this research shows that, indeed.

The results of compressive strength for ARI and RS exposed along 20 weeks (140 days) for the 3 different solutions are shown in Figure $7\left[\mathrm{Ca}(\mathrm{OH})_{2}\right]$; sodium sulfate; and magnesium sulfate. The results of compressive strength at 42 days of exposure showed the similarity between the influences of the final solutions for 6 weeks tested. In the same way, the similarity in performance due

Table 3

The starting point of micro-cracking of the samples exposed to $\mathrm{Na}_{2} \mathrm{SO}_{4}$ and $\mathrm{MgSO}_{4}$ solutions

\begin{tabular}{|c|c|c|c|c|}
\hline \multicolumn{5}{|c|}{ Micro-cracking starting point (weeks) } \\
\hline Sample & Solution & $\frac{d y}{d t}=0$ & Solution & $\frac{d y}{d t}=0$ \\
\hline ARI & \multirow{2}{*}{$\mathrm{Na}_{2} \mathrm{SO}_{4}$} & 3,69 & \multirow{2}{*}{$\mathrm{MgSO}_{4}$} & 11,00 \\
\hline RS & & 7,98 & & 5,50 \\
\hline
\end{tabular}




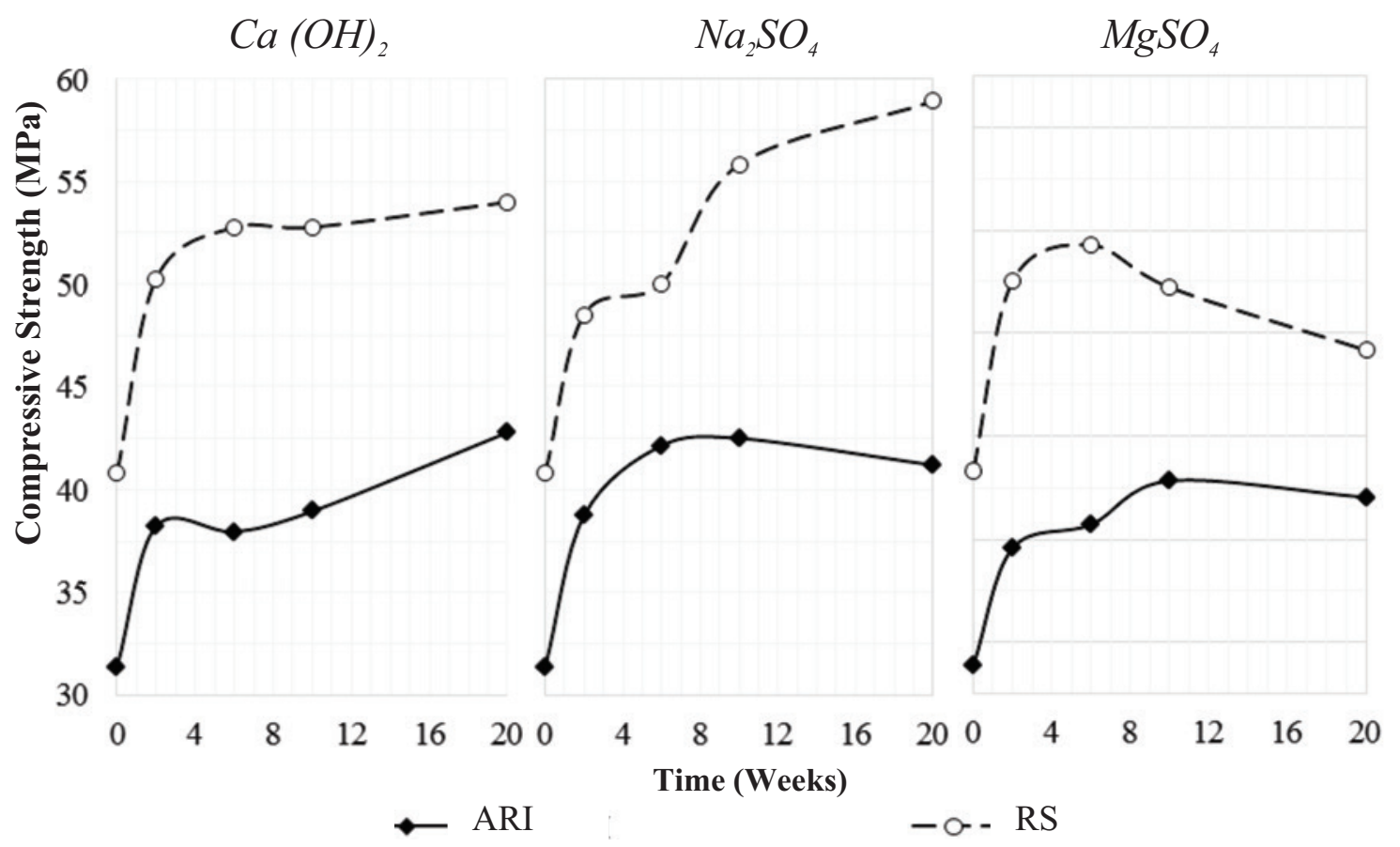

\section{Figure 7}

Compressive strength of the samples up to 20 weeks of exposure in the three different solutions $\left(\mathrm{Ca}[\mathrm{OH}]_{2}, \mathrm{Na}_{2} \mathrm{SO}_{4}\right.$ and $\left.\mathrm{MgSO}_{4}\right)$

to the different solutions at low exposure times, Figure 8 shows the Tukey's test results for comparison of the equivalence among them but exposed to the different solutions. And, as can be seen, the exposure solution does not has influence on the results of compressive strength for short periods of exposure (42 days, exposure time recommended by NBR 13.583).

Regarding 20 weeks of exposure, it is seen that the chemical compositions of the cement used have directly impact on the results related to sulfate attack. For example, the $\mathrm{Ca} / \mathrm{Si}$ ratio of the cement varied from 3.65 (ARI) to 2.76 (ARI RS), and according to Tikalsky et al. [15], Bellmann and Stark [18] and Lothenbach et al. [19], the decrease in this ratio implies in a reduction in the amount of portlandite after hydration, therefore, this turns the composition more resistant to sodium sulfate attack. On the other hand, for magne- sium sulfate attack, such reduction results in a composition more susceptible to the damage [8][20]. Thus, for both cases, what was seen was, precisely, a behavior of the samples according to information obtained in the literature.

In the direct comparison between binders, it can be seen that the changes on the chemical composition have a huge influence on the results of compressive strength and, especially, a significant variation on the behavior regarding solutions of sodium and magnesium sulfate (Figure 9).

The exposure of the ARI to both sulfate solutions showed, in general, a reduction in the compressive strengths for 20 weeks of analysis could be seen, and could even be considered statistically equivalent. Therefore, it is concluded that the interaction, either $\mathrm{Na}_{2} \mathrm{SO}_{4}$ or $\mathrm{MgSO}_{4}$, obtained the same behavior for ARI (Figure 8).

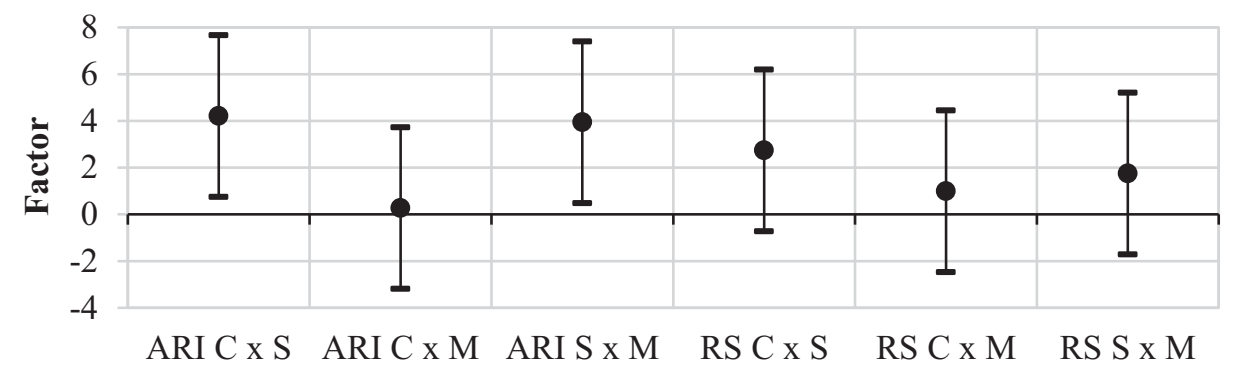

\section{Figure 8}

Comparison between averages of compressive strength (Tukey test for a significance level of $5 \%$ ) of the same series for different aggressive solutions ( $\mathrm{C}$ - calcium hydroxide, $\mathrm{S}$ - sodium sulfate and $\mathrm{M}$ - magnesium sulfate) for 6 weeks of exposure 
The most relevant difference between solutions for ARI was the comparison of $\mathrm{CH}$ solution and magnesium sulfate, where there was a more pronounced loss of strength for exposure to $\mathrm{MgSO}_{4}$, whereas for the $\mathrm{CH}$ solution the resistance remained stable.

On the other hand, the same statement cannot be done for RS, in this case, which was seen were complete different behaviors for both aggressive solutions, indicating that the cations associated with sulfate ions also has an influence on the damage degree of the attack. For example, it was seen that RS exhibits a higher reduction in compressive strength at 20 weeks when exposed to $\mathrm{MgSO}_{4}$, with a total loss of $17.9 \%$ than the result of compressive strength obtained due to exposure to calcium hydroxide, this corresponds to a loss of $7.4 \mathrm{MPa}$. This variation, according to Skalny et al. [2] and Lee et al. [31] is associated with the decalcification of the $\mathrm{C}-\mathrm{S}-\mathrm{H}$, and, consequently, the formation of $\mathrm{M}-\mathrm{S}-\mathrm{H}$, which have little or no bonding and strength characteristics [31].

Thus, these results are reliable with the theory and experiments analyzed in the literature [8][32][33], the loss of strength is much more significant than the actual length variation of samples exposed to magnesium sulfate attack.

These results bring important information regarding the degradation of the sulfate attack, especially when it makes a parallel with real concrete structures since these are always projected based on compressive strength. At the same time, such degradation was not observed for linear dimensional expansion, so it was confirmed that "quantify" sulfate attack only by the use of one-dimensional behavior can lead to errors in decision-making to define the materials to be used at the field.

On the other hand, when analyzed the results for exposure to sodium sulfate, what could be seen was a $9.1 \%$ of the increase in compressive strength, equivalent to a gain of 4.9 MPa. However, as discussed previously, RS obtained a low expansion results, then, analyzing both results together, may lead to conclusions that, in fact, there was, indeed, the interaction between mortars and sulfate ions, but with a lower rate. However, this is not a reliable behavior, considering that in the comparative analysis between averages for the interaction of the solutions in the same mortar composition (Figure 10), it shows that the RS exposed to

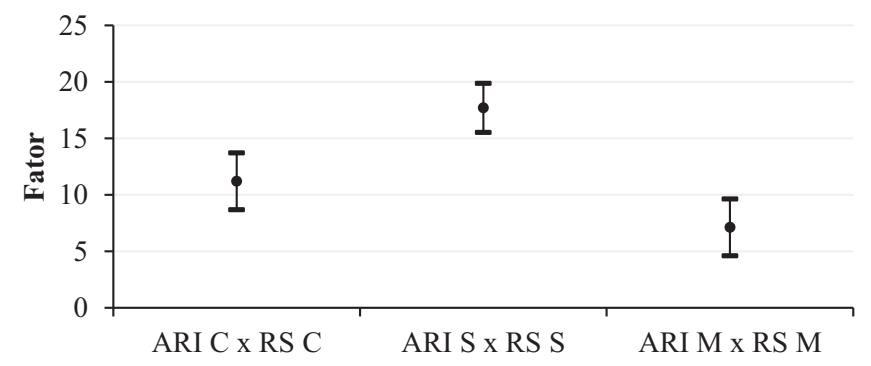

\section{Figure 9}

Comparison between compressive strength average (Tukey test for a significance level of 5\%) of ARI and RS series for different aggressive solutions (C - calcium hydroxide, S - sodium sulfate and $\mathrm{M}$ - magnesium sulfate) for 20 weeks of exposure

$\mathrm{CH}$ and sodium sulfate presented different behavior. Therefore, the $\mathrm{Na}_{2} \mathrm{SO}_{4}$ solution has influenced the results, taking into account the statements made by Biczók [1] and Ouyang et al. [34]. The authors commented that samples exposed to the sodium sulfate solution, at an "early" development of the attack, have increased strength. Also, Ouyang et al. [34] analyzed the surface hardness gain of the concrete exposed to $\mathrm{Na}_{2} \mathrm{SO}_{4}$ obtained significant increases of values in the early development of the attack, and an abrupt loss for surface hardness values at longer exposure times. This behavior can be explained by the fact that the pores of the mortars, or concrete, are firstly filled by crystals (Gypsum and Ettringite) formed with sulfate reactions, decreasing porosity. However, these crystals continue to gain volume so far, in which, they begin to crack the matrix when tensile strength is overcome, being this the point whose strength loss starts.

Thus, the achievement micro-cracking start time point, as seen in the results of tensile strength, corroborate these statements. That is, there were indications that the process of degradation of cement mortars RS has already begun, which may indicate that in field, this type of cement maybe will show damage after long periods of exposure.

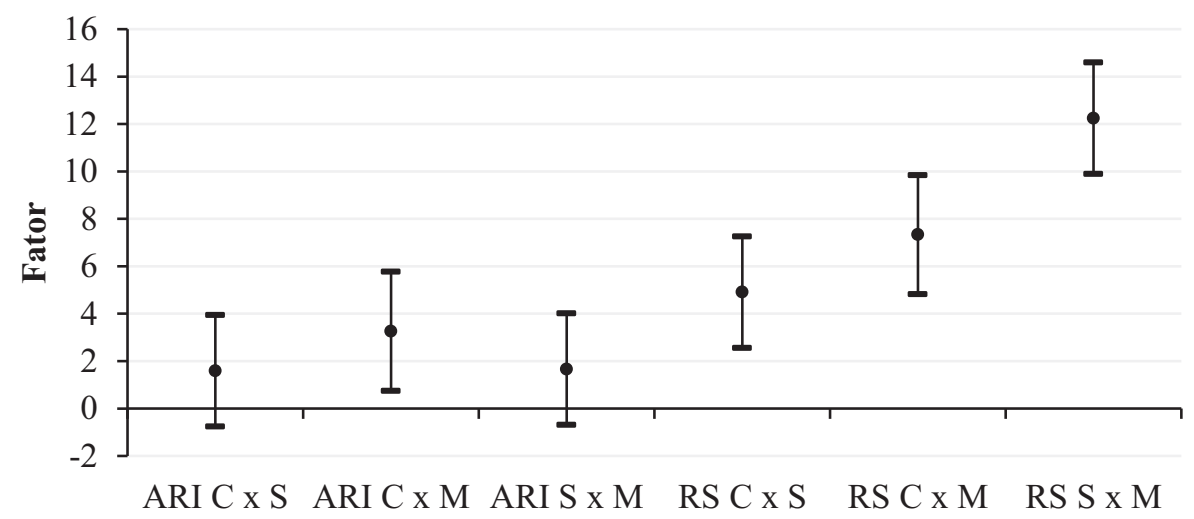

\section{Figure 10}

Comparative analysis between compressive strength averages (Tukey test for a significance level of 5\%) of the same composition series for different aggressive solutions ( $\mathrm{C}$ - calcium hydroxide, $\mathrm{S}$ - sodium sulfate and $\mathrm{M}$ - magnesium sulfate) for 20 weeks of exposure 
Finally, the evaluation length variation only can lead to erroneous conclusions that the attack by magnesium sulfate does not generate large deteriorations in the concrete, mortars or pastes when compared in a same period of time for solution of $\mathrm{Na}_{2} \mathrm{SO}_{4}$. However, such results show a contrary reality, leading one to believe that the analysis of the sulfate attack may be insufficient when evaluated only by linear dimensional variation. What is contradictory with the recommendation of NBR 13.583 [25].

\section{Conclusions}

It was verified that the chemical compositions of the cement directly influence the degree of the sulfate attack, however, in a different way between aggressive solutions tested. It was observed that the $\mathrm{C}_{3} \mathrm{~S}_{\mathrm{C}} \mathrm{S}$ ratio of the clinker has opposite influences for both sulfate solutions (sodium and magnesium sulfate). As higher this ratio was, more vulnerable the composition will be to $\mathrm{Na}_{2} \mathrm{SO}_{4}$, whereas for $\mathrm{MgSO}_{4}$, the ratio becomes more harmful to lower values. Nevertheless, it was verified that the decrease in the $\mathrm{C}_{3} \mathrm{~A} / \mathrm{C}_{4} \mathrm{AF}$ ratio change the kinetics of the reaction and reduce the expansion process for exposure to $\mathrm{Na}_{2} \mathrm{SO}_{4}$ since the production of ettringite from $\mathrm{C}_{4} \mathrm{AF}$ occurs in periods much longer than $\mathrm{C}_{3} \mathrm{~A}$. However, this relationship has little influence when analyzed exposure to magnesium sulfate attack.

The cement studied, sold in the Brazilian market as resistant to sulfates, was, in fact, resistant to sodium sulfate attack, fulfilling all the requirements required by the norm.

However, when evaluated for long exposure time, it was observed that sodium sulfate influenced the results of compressive strength and also tensile strength of the mortars composed with sulfate resistant cement, indicating, that there is a probability of degradation and loss in durability for longer exposure times than those that analyzed in this research.

However, the same behavior did not occur for exposure to magnesium sulfate, because the RS cement presented significant premature degradation, regarding the starting point of microcracking, when compared to the reference (ARI). And, at the same time, showing an expressive loss in compressive strength. Therefore, indicating that sulfate resistant cement, as sold in the Brazilian market, is not a good option when it comes to exposure to $\mathrm{MgSO}_{4}$

\section{Acknowledgment}

The authors would like to thanks the support of the Graduation Program in Civil Construction Engineering at Federal University of Paraná (DCC-PPGECC-UFPR), the Ponta Grossa State University (UEPG), the Federal University of Western Bahia (UFOB), the National Council for Scientific and Technological Development (CNPq) and the Coordination for the Improvement of Higher Education Personnel (CAPES).

\section{References}

[1] BICZÓK, I. La corrosion del hormigon y su proteccion. Tradução de: ASENSI, E. J.D. 1. ed. Bilbao, Espanha: URMO, 1972
[2] SKALNY, J.; MARCHAND, J.; ODLER, I. Sulfate Attack on Concrete. 1. ed. Londres: SPON PRESS, 2002.

[3] Al-AKHRAS, N. M. Durability of metakaolin concrete to sulfate attack. Cement and Concrete Research, Vol. 36, p. $1727-1734,2006$.

[4] NEVILLE, A.; BROOKS, J. J. Tecnologia do concrete. 2 ed. Porto Alegre: Bookman, 2013.

[5] BROWN, P. B. Thaumasite formation and other forms of sulfate attack. Cement and Concrete Research, Vol. 24, p. $301-303,2002$.

[6] HOOTON, R. D. Influence of silica fume replacement of cement on physical properties and resistance to sulfate attack, freezing and thawing, and alkali-silica reactivity. ACI Materials Journal, Vol. 90, p. 143 - 151, 1993.

[7] NEVILLE, A. Propriedades do concreto. Tradução de: GIAMMUSSO, S. E. 2. ed. São Paulo: PINI, 1997.

[8] SANTHANAM, M.; COHEN, M. D.; OLEK, J. Mechanism of sulfate attack: A fresh look: Part 1: Summary of experimental results. Cement and Concrete Research, Vol. 32, p. 915 - 921, 2002.

[9] NEVILLE, A. The confused world of sulfate attack on concrete. Cement and Concrete Research, Vol. 34, p. 1275 - 1296, 2004.

[10] BEHFARNIA, K.; FARSHADFAR, O. The effects of pozzolanic binders and polypropylene fibers on the durability of SCC to magnesium sulfate attack. Construction and Building Materials, Vol. 38, p. 64 - 71, 2013.

[11] MEHTA, P. K.; MONTEIRO, P. J. M. Concreto - Microestrutura, propriedades e materiais. 3 ed. São Paulo: IBRACON, 2014.

[12] CHATVEERA, B.; LERTWATTANAURUK, P. Evaluation of sulfate resistance of cement mortars containing black rice husk ash. Journal of Environmental Management, Vol. 90, p. 1435 - 1441, 2009.

[13] COHEN, M. D.; BENTUR, A. Durability of Portland Cement - silica fume pastes in magnesium sulfate and sodium sulfate solutions. ACI Materials Journal, Vol. 85, p. 148 - 157, 1998.

[14] ASSOCIAÇÃO BRASILEIRA DE NORMAS TÉCNICAS. NBR 5737: Cimentos Portland resistentes a sulfatos. Rio de Janeiro, 1992.

[15] TIKALSKY, P. J.; ROY, D.; SCHEETZ, B.; KRIZE, T. Redefining cement characteristics for sulfate-resistant Portland cement. Cement and Concrete Research. Vol.32, p.1239-1246, 2002.

[16] TOSUN-FELEKOGLU, K. The effect of C3A content on sulfate durability of Portland limestone cement mortars. Construction and Building Materials. Vol. 36, p.437-447, 2012.

[17] HOSSACK, A. M.; THOMAS, M. D. A. Evaluation of the effect of tricalcium aluminate content on the severity of sulfate attack in Portland cement and Portland limestone cement mortars. Cement \& Concrete Composites, Vol. 56, p. $115-120,2015$.

[18] BELLMANN, F.; STARK, J. Prevention of thaumasite formation in concrete exposed to sulphate attack. Cement and Concrete Research, Vol. 37, p. 1215 - 1222, 2007. 
[19] LOTHENBACH, B.; SCRIVENER, K.; HOOTON, R.D. Supplementary cementitious materials, Cement and Concrete Research, Vol. 41, p. 1244 - 1256, 2011.

[20] TAYLOR, H. F. W. Cement Chemistry. 2. ed. London: Thomas Telford, 1997.

[21] ASSOCIAÇÃO BRASILEIRA DE NORMAS TÉCNICAS. NBR NM 18: Cimento Portland - Análise química - Determinação de perda ao fogo. Rio de Janeiro, 2012.

[22] ASSOCIAÇÃO BRASILEIRA DE NORMAS TÉCNICAS. NBR NM 23: Cimento portland e outros materiais em pó - Determinação da massa específica. Rio de Janeiro, 2001.

[23] ASSOCIAÇÃO BRASILEIRA DE NORMAS TÉCNICAS. NBR 16372: Cimento Portland e outros materiais em pó - Determinação da finura pelo método de permeabilidade ao ar (método de Blaine). Rio de Janeiro, 2015.

[24] ASSOCIAÇÃO BRASILEIRA DE NORMAS TÉCNICAS. NBR 7214: Areia normal para ensaio de cimento - Especificação. Rio de Janeiro, 2012.

[25] ASSOCIAÇÃO BRASILEIRA DE NORMAS TÉCNICAS. NBR 13583: Cimento Portland - Determinação da variação dimensional de barras de argamassa de cimento Portland expostas à solução de sulfato de sódio. Rio de Janeiro, 2014.

[26] ASSOCIAÇÃO BRASILEIRA DE NORMAS TÉCNICAS. NBR 7215: Cimento Portland - Determinação da resistência à compressão. Rio de Janeiro, 1997.

[27] ASSOCIAÇÃO BRASILEIRA DE NORMAS TÉCNICAS. NBR 13279: Argamassa para assentamento e revestimento de paredes e tetos - Determinação da resistência à tração n flexão e à compressão. Rio de Janeiro, 2005.

[28] MARCIANO, Z. A. N. Desenvolvimento de um método acelerado para avaliação da resistência de argamassas de cimento Portland expostas à solução de sulfato de sódio. 1993. 202 f. Dissertação (Mestrado em Engenharia) - Universidade de São Paulo, São Paulo, 1993.

[29] IRASSAR, E. F. Sulfate resistance of blended cement: Prediction and relation with flexural strength. Cement and Concrete Research, Vol. 20, p. 209 - 218, 1990.

[30] HUANG, Q.; WANG, C.; YANG, C.; ZHOU, L.; YIN, J. Accelerated sulfate attack on mortars using electrical pulse. Construction and Building Materials, vol. 95, p. 875-881, 2015.

[31] LEE, S. T.; MOON, H. Y.; HOOTON, R. D.; KIM, J. P. Effect of solution concentrations and replacement levels of metakaolin on the resistance of mortars exposed to magnesium sulfate solutions, Cement and Concrete Research, Vol. 35, p. 1314 - 1323, 2005.

[32] DIAB, A. M.; AWAD, A. E. M.; ELYAMANY, H. E.; ELMOATY, A. E. M. A. Guidelines in compressive strength assessment of concrete modified with silica fume due to magnesium sulfate attack. Construction and Building Materials, Vol. 36, p. $311-318,2012$.

[33] HEKAL, E. E.; KISHAR, E.; MOSTAFA, H. Magnesium sulfate attack on hardened blended cement pastes under different circumstances. Cement and Concrete Research, Vol. 32, p. 1421 - 1427, 2002.
[34] OUYANG, W.; CHEN, J.; JIANG, M. Evolution of surface hardness of concrete under sulfate attack. Construction and Building Materials, Vol. 53, p. 419-424, 2014. 